\title{
Food protein induced enterocolitis to fish in children
}

\author{
Purificacion Gonzalez-Delgado ${ }^{1 *}$, M. Victoria Moreno², Fernando Clemente ${ }^{3}$, Esther Caparros ${ }^{2}$, Javier Fernandez ${ }^{1}$ \\ From Food Allergy and Anaphylaxis Meeting 2014 \\ Dublin, Ireland. 9-11 October 2014
}

Food protein induced enterocolitis syndrome (FPIES) is a severe infantile form of cell-mediated, food hypersensitivity caused typically by cow`s milk and/or soy characterized by profuse vomiting and diarrhea, with progression to dehydration and shock in some cases. FPIES caused by fish is uncommon.

\section{Methods}

Children admitted for evaluation of gastrointestinal symptoms after fish ingestion. Skin Prick Tets (SPT) with commercial extracts of codfish, hake, sole, tuna, herring, haddock were performed. Specific IgE to fish was also determined.

Patch test with the same extracts for SPT were applied $48 \mathrm{~h}$ and read at 2 and 24 hours after removing. Open Oral challenge (OOC) was performed when diagnosis was not clearly established with clinical history.

\section{Results}

We report 14 children with FPIES caused by fish. All had negative SPT to fish. Serum specific IgE was undetectable in all.

Median age at the diagnosis was 9.46 months (8-11).

Diagnosis was established after a median of 4 previous reactions (3-5).

Symptoms appeared 1-4 hours after intake (median 2h). 9 patients were treated in Emergency room because profuse vomiting, 3 were admitted in Pediatric Intensive Care Unit as they developed shock with hypotension. OOC was performed in 3 patients being positive.

Patch test were positive in $6 / 14$ patients.

\section{Conclusions}

We communicate 14 patients with FPIES induced by fish. Diagnosis of FPIES especially when triggered by

\footnotetext{
${ }^{1}$ Allergy Unit, General Hospital Alicante, Alicante, Spain
}

Full list of author information is available at the end of the article fish is often delayed because of a low index of suspicion and clinical features that overlap with sepsis and with other diseases. Sensitivity of patch test was $42.8 \%$.

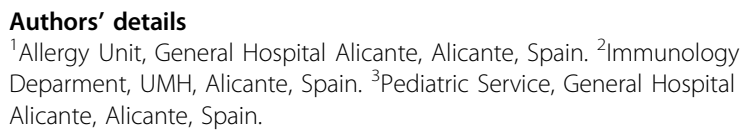

${ }^{1}$ Allergy Unit, General Hospital Alicante, Alicante, Spain. ${ }^{2}$ Immunology Deparment, UMH, Alicante, Spain. ${ }^{3}$ Pediatric Service, General Hospital Alicante, Alicante, Spain.

Published: 30 March 2015

doi:10.1186/2045-7022-5-S3-P28

Cite this article as: Gonzalez-Delgado et al:: Food protein induced enterocolitis to fish in children. Clinical and Translational Allergy 2015 5(Suppl 3):P28.

\section{Submit your next manuscript to BioMed Central and take full advantage of: \\ - Convenient online submission \\ - Thorough peer review \\ - No space constraints or color figure charges \\ - Immediate publication on acceptance \\ - Inclusion in PubMed, CAS, Scopus and Google Scholar \\ - Research which is freely available for redistribution \\ Submit your manuscript at www.biomedcentral.com/submit}

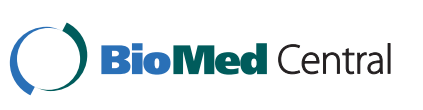

(c) 2015 Gonzalez-Delgado et al; licensee BioMed Central Ltd. This is an Open Access article distributed under the terms of the Creative Commons Attribution License (http://creativecommons.org/licenses/by/4.0), which permits unrestricted use, distribution, and reproduction in any medium, provided the original work is properly cited. The Creative Commons Public Domain Dedication waiver (http://creativecommons.org/publicdomain/zero/1.0/) applies to the data made available in this article, unless otherwise stated. 